This may partly be explained by the fact that even severely dysphagic people do not always volunteer symptoms, as shown by the six subjects in our study who had never consulted a doctor for their daily discomfort during meals. The tendency for elderly people to accept their problems as an inevitable manifestation of old age is probably the cause of this failure to seek help, ${ }^{3}$ resulting in underreporting of symptoms so that the actual prevalence of dysphagia may be even higher than our findings suggest. Moreover, by selecting subjects living in the community we may have excluded less healthy people, thus further underestimating the prevalence of dysphagia.

The relative extent to which dysphagia is caused by either aging or specific diseases is unknown. Our findings show a high correlation between dysphagia

and diseases of the central nervous system and oesophagus. The cause of dysphagia in people not reporting specific diseases, however, remains uncertain, so aging as a cause of senile dysphagia cannot be excluded.

This study was part of a project financed by National Institutes of Health grant 5 ROl AG06354 A M Lagaay and W van Beek). We thank W Hijmans for advice and $\mathrm{E} A$ van der Velde for the statistical analysis.

1 Borgstrom PS, Ekberg O. Pharyngeal dysfunction in the elderly. Fournal of Medical Imaging 1988;2:74-81

2 Folstein MF, Folstein SE, McHugh PR. "Mini-mental state": a practical method for grading the cognitive state of patients for the clinician. I lswchiutr $^{\text {s. }}$ $R \backsim 1975: 12: 189-98$

3 Rowe JW. Health care of the elderly. N Engl F Med 1985;312:827-35.

(Accepted 21 December 1989)

\title{
Use of skin thermometer to diagnose acute appendicitis
}

\section{J E Hambidge}

Princess Alexandra's Hospital, Wroughton, Wiltshire SN4 0QJ $\mathrm{J}$ E Hambidge, FRCंSED, registrar in surgery

Correspondence to: Mr J E Hambidge, Princess Mary's Royal Air Force Hospital, Halton, Aylesbury,

Buckinghamshire HP22 5PS.

$\operatorname{BrMed~f~1990;300:722~}$
Diagnosing appendicitis before operation is often difficult, especially in children.' Thus $15-20 \%$ of appendicectomies are unnecessary on clinical grounds alone. ${ }^{2}$ Various tests have been suggested to increase the accuracy of diagnosis, including the white cell count and thermography. The white cell count is insensitive, but its sensitivity can be improved by combining it with estimations of $\mathrm{C}$ reactive protein concentration and erythrocyte sedimentation rate. ${ }^{3}$ Steele found that thermography had no value as a diagnostic technique, ${ }^{+}$although a Russian study showed that local skin temperature in the right iliac fossa may be a useful indicator. ${ }^{5}$ I studied the accuracy of using a thermometer that is usually used on children's foreheads (Feverscan; Robinsons of Chesterfield) in diagnosing appendicitis.

\section{Patients, methods, and results}

The thermometer measures skin temperature to the nearest degree Celsius and has a range from $35-40^{\circ} \mathrm{C}$. A reading is taken after it has been held to the skin for 15 seconds. Twenty five consecutive patients who had already been selected for appendicectomy by routine clinical assessment had their skin temperature measured before the operation. The temperature was measured over McBurney's point and a corresponding position on the left. Patients were considered to have acute appendicitis if the skin temperature on the right was at least $1^{\circ} \mathrm{C}$ warmer than that on the left. Surgical findings and histological results were noted. Twenty five consecutive patients admitted for planned orthopaedic procedures (controls) were similarly assessed.

The table shows the results. Negative results were obtained for all the controls, and all the patients in whom the response was positive had appendicitis. Some false negative results occurred.
Results of using Feverscan thermometer to diagnose appendicitis

\begin{tabular}{lccc}
\hline & $\begin{array}{c}\text { No of positive } \\
\text { results }\end{array}$ & $\begin{array}{c}\text { No of negative } \\
\text { results }\end{array}$ & Total \\
\hline Patients: & & 8 & \\
$\quad$ With appendicitis & 14 & 3 & 22 \\
$\quad$ Without appendicitis & & 25 & 25 \\
Controls & & 36 & 50 \\
\hline Total & 14 & 36 \\
\hline
\end{tabular}

^Appendicitis confirmed by histological examination after operation.

\section{Comment}

These results show that the test has a sensitivity of $64 \%$, a specificity of $100 \%$, a positive predictive value of $100 \%$, a negative predictive value of $27 \%$, and an overall accuracy of $68 \%$. If the negative results from the control group are included the negative predictive value is increased to $78 \%$ and the accuracy to $84 \%$. Although a negative result did not exclude appendicitis, a positive result always indicated it.

The Feverscan thermometer is accurate only to the nearest degree Celsius. Other, more accurate methods of assessing skin temperature are available, but they do not have the benefits of being easy to use, portable, and inexpensive.

Thermography has been reported in one study to be of little use in diagnosing appendicitis. ${ }^{4} \mathrm{My}$ results, on the other hand, support those of a Russian study that showed the technique to be of value. I now intend to carry out a larger study, using the Feverscan thermometer to assess all patients presenting with acute abdominal pain.

\section{O'Shea JS, Bishop ME, Alario AJ, Cooper JM. Diagnosing appendicitis in children with acute abdominal pain. Pediatr Emerg Care 1988;4:172-6. \\ 2 Blind PJ, Dahlgren ST. The continuing challenge of the negative appendix. Acta Chir Scand 1986:152:623-7. \\ 3 Marchand A Van Lente F. Galen RS. The assessment of laboratory tests in the diagnosis of acute appendicitis. Am 7 Clin Pathol 1983;80:369-74. \\ 4 Steele RJ. Abdominal thermography in acute appendicitis. Scott Med $\mathscr{f}$ 1986;31:299-30 \\ 5 Zakharov SN, Svitich IM, Baskakov VA. Electrothermometry in the diagnosi of destructive forms of acute appendicitis and acute cholecystitis. Khirurgiic (Sofiia) 1981;10:37-9.}

(Accepted 1 December 1989)

\section{ONE HUNDRED YEARS AGO}

On his arrival at Alexandria on January 22nd, Surgeon Parke was welcomed by Brigade-Surgeon Gore, Senior Medical Officer of the Alexandria garrison. Surgeon Parke was serving at Alexandria up to February 2nd, 1887, when he started to join Stanley, and was, therefore, among old friends on returning to that city last month; by them he was entertained at a dinner over which Sir Charles A. Cookson, K.C.M.G., C.B., presided. Speaking in response to the toast of his health, Surgeon Parke gave a short account of the difficulties which the expedition had encountered, and spoke in warm terms of the energy and determination of its leader. Referring to the health of the expeditionary force, he said that the experience it had afforded appeared to prove that the white man had a better chance than the black man of living in Africa, for out of eleven white men only one life was lost, while considerably more than half the blacks perished. Dr. Parke considered it augured well for the future of Africa that it was proved that it could be colonised by white men. (British Medical Fournal 1890;i:310.) 